\title{
Development of a Coulometric Method for the Determination of Gaseous Sulfur Compounds in Urban Atmospheres
}

\author{
Magali Silva and Luis F. P. Dick* \\ Departamento de Metalurgia, Universidade Federal do Rio Grande do Sul, \\ Av. Osvaldo Aranha, 99/6ªndar, 90035-190, Porto Alegre - RS, Brazil
}

\begin{abstract}
Uma nova metodologia para a determinação de compostos gasosos de enxofre presentes em atmosferas urbanas foi desenvolvida e aplicada durante três meses na região central da cidade de Porto Alegre- RS e em uma refinaria de petróleo, localizada próxima à essa cidade. O método se baseia na determinação coulométrica da taxa de sulfetação da prata pura. Os resultados foram comparados com o método da pararosanilina, que está sendo atualmente utilizado para a determinação de $\mathrm{SO}_{2}$ em alguns dos locais aqui estudados. Os resultados obtidos mostraram que uma boa correlação entre o método coulométrico e o método da pararosanilina é observada quando somente $\mathrm{SO}_{2}$ está presente, como normalmente é esperado para atmosferas urbanas. Quando $\mathrm{H}_{2} \mathrm{~S}$ está também presente, como no caso das áreas industriais, a nova metodologia tende fortemente a super estimar derivados gasosos de enxofre.
\end{abstract}

A new procedure for the determination of atmospheric sulfur compounds was developed and applied during three months in the central area of the City of Porto Alegre- RS, and one month near an oil refinery located close to this city. The method is based on the coulometric determination of the tarnishing rate of pure silver. The results were compared with the method of pararosaniline, which is being currently used in some of the studied sites for the determination of $\mathrm{SO}_{2}$. The results obtained showed a good correlation between the coulometric method and the pararosaniline method, when only $\mathrm{SO}_{2}$ is present, as usually is the case of urban atmospheres. When $\mathrm{H}_{2} \mathrm{~S}$ is also present, as in the case of industrial areas, the methodology tends to strongly overestimate $\mathrm{SO}_{2}$ concentration.

Keywords: coulometric method, tarnishing of $\mathrm{Ag}$, urban pollution, $\mathrm{SO}_{2}, \mathrm{H}_{2} \mathrm{~S}$

\section{Introduction}

Besides suspended particles, gaseous compounds, such as carbon monoxide $(\mathrm{CO})$, carbon dioxide $\left(\mathrm{CO}_{2}\right)$ and sulfur dioxide $\left(\mathrm{SO}_{2}\right)$, are normally the main atmospheric pollutants in urban areas 1, 2. Previous studies showed that in Porto Alegre- RS, approximatly 3.7 tons of $\mathrm{SO}_{\mathrm{x}}$ are daily emitted. Further 3.4 tons of $\mathrm{SO}_{\mathrm{x}}$ per day are produced in the industrial metropolitan area around the city 3 .

The main $\mathrm{SO}_{2}$ source in urban areas is commonly accepted as resulting from the use of fossil fuels. In warm regions like Southern Brazil, the main source should be attributed to the transport activity and to the use of Diesel

*e-mail: lfdick@vortex.ufrgs.br

Presented at the XI Simpósio Brasileiro de Eletroquímica e Eletroanalítica, Maragogi - AL, Brazil, April 5-9, 1999. Guest editor: Luis Alberto Avaca. oil. Due to local variations in the traffic density and in the wind velocity in a city, a local monitoring of $\mathrm{SO}_{2}$ is more adequate to identify critical areas, which are harmful to the human health and are also very corrosive to metals, stones and concrete structures.

The aim of the present study was to develop a method for the determination of atmospheric $\mathrm{SO}_{2}$ content. The method should be inexpensive and simple, making possible the local determination of the mean concentration in several points in an urban area. As showed below, the tarnishing rate of silver shows the desired characteristics for an indicator of the $\mathrm{SO}_{2}$ concentration.

Pure silver, when exposed to $\mathrm{H}_{2} \mathrm{~S}$ or $\mathrm{SO}_{2}$, forms a tarnishing layer consisting only of achantite (alpha $\mathrm{Ag}_{2} \mathrm{~S}$ ). This sulfide has an extremely low solubility product in water, $\mathrm{K}_{\mathrm{ps}}=110^{-50} \mathrm{~mol} \mathrm{~L}^{-1} 3,4$ and is very conductive and adherent to the silver surface, enabling its coulometric determination after the atmospheric exposure of $\operatorname{silver}^{3}, 5$. 
Moreover, due to the high mobility of $\mathrm{Ag}^{+}$ions in the $\mathrm{Ag}_{2} \mathrm{~S}$ salt, the tarnishing rate is time independent for tarnishing layers up to several microns thick, being directly proportional to the $\mathrm{H}_{2} \mathrm{~S}$ and $\mathrm{SO}_{2}$ concentrations ${ }^{5}$. As an example, the tarnishing rate of $\mathrm{Ag}$ in $1 \mathrm{ppm} \mathrm{H}_{2} \mathrm{~S}$, which is higher than the one in $\mathrm{SO}_{2}$, remains controlled by surface reaction for several days 6,7 .

The results presented here were measured during the southern hemisphere summer of 1999 in three urban points of Porto Alegre- RS, showing heavy traffic, where only $\mathrm{SO}_{2}$ is expected, and also in two sites near an oil refinery, with different distances from a $\mathrm{H}_{2} \mathrm{~S}$ source. An increasing $\mathrm{SO}_{2} / \mathrm{H}_{2} \mathrm{~S}$ concentration ratio is expected here for greater distances from the $\mathrm{H}_{2} \mathrm{~S}$ source, resulting from the oxidation of $\mathrm{H}_{2} \mathrm{~S}$ to $\mathrm{SO}_{2}$ during its transport from the source to the measuring site. A long-term study is now under way to determine the influence of traffic intensity and climate parameters in the correlation between the coulometric and pararosaniline methods.

\section{Experimental}

For the coulometric determination of tarnishing rates, coupons of pure silver (Sigma-Aldrich, $99.99 \% \mathrm{Ag}$ ) with geometric areas between 5 and $6 \mathrm{~cm}^{2}$ were cut and provided with a $0.5 \mathrm{~mm}$ diameter hole. After vacuum annealing $\left(650{ }^{\circ} \mathrm{C} \mathrm{h}^{-1} 10^{-2} \mathrm{~atm}\right)$ the coupons were polished on both sides with emery paper up to 2400 mesh and degreased in ethanol. For the atmospheric exposure, the coupons were hanged by a PTFE thread in the vertical position at five "monitoring stations", where a good ventilation and rain protection were provided, and also other atmospheric data were being collected. Three monitoring stations were located in downtown sites, with dense traffic, Rodoviária, Borges and Azenha. Among these sites, Rodoviária, where the Central Bus Station is located, shows usually the highest $\mathrm{SO}_{2}$ emissions. The other two monitoring stations were located at $19 \mathrm{~km}$ far from downtown of Porto Alegre- RS, at the oil refinery "Refinaria Alberto Pasqualine-Petrobras", namely REFAP1 and REFAP 2 . The station REFAP 1 lied $750 \mathrm{~m}$ far from an $\mathrm{H}_{2} \mathrm{~S}_{-} \mathrm{SO}_{2}$-source, and REFAP2, respectively $1,500 \mathrm{~m}$. At three of these stations, Rodoviária, REFAP1 and REFAP2, $\mathrm{SO}_{2}$ was also collected and the concentration determined by the pararosaniline method as described in the appropriate norm ${ }^{8}$. The exposures were proceeded from January to March 1999. The mean relative humidity and temperature during this period were $79.4 \%$ and $24.9{ }^{\circ} \mathrm{C}$ respectively, as determined for Porto Alegre- RS by the local state climate station.

After exposure for different times, the $\mathrm{Ag}$ coupons were rinsed with water and acetone and reduced potentiodynamically in a standard three electrodes cell. The electrolyte was a borate buffer of $\mathrm{pH} 10\left(3.092 \mathrm{~g} \mathrm{~L}^{-1} \mathrm{H}_{3} \mathrm{BO}_{3}, 3.728 \mathrm{~g} \mathrm{~L}^{-1} \mathrm{KCl}\right.$, $1.756 \mathrm{~g} \mathrm{~L}^{-1} \mathrm{NaOH}$ ), with addition of small quantities of $\mathrm{Na}_{2} \mathrm{~S}$ and purged previously for $8 \mathrm{~h}$ with $\mathrm{N}_{2}$. Good results were obtained for sweep velocities in the negative direction of 0.1 $\mathrm{mV} \mathrm{s}^{-1}$, starting from the $\mathrm{Ag}_{2} \mathrm{~S} / \mathrm{Ag}$ equilibrium potential. This low sweeping rate was necessary to avoid the superposition of the $\mathrm{Ag}_{2} \mathrm{~S}$ reduction peak and the current related to the hydrogen evolution reaction. The equilibrium potential $\left(\mathrm{Ag}_{2} \mathrm{~S} / \mathrm{Ag}\right)$ was determined by a previous potentiodynamic sulfidation and reduction of a blank Ag probe in the same solution. The potentials were measured against an $\mathrm{AgCl} / \mathrm{Ag}$ reference electrode in $3.5 \mathrm{~mol} \mathrm{~L}^{-1} \mathrm{KCl}$, but are referred in the text to the normal hydrogen electrode (NHE). After data acquisition by computer, the mass of $\mathrm{Ag}_{2} \mathrm{~S}$ per area was calculated from the charge density under the observed cathodic peak, assuming $\mathrm{Ag}_{2} \mathrm{~S}$ as the only tarnishing product and subtracting the charge related to the background current density.

\section{Results and Discussion}

The voltammograms of the reduction of the exposed Ag coupons are shown in Figures from 1 to 5. A sharp reduction peak in the range between $\mathrm{E}\left(\mathrm{Ag}_{2} \mathrm{~S} / \mathrm{Ag}\right)$ and $200 \mathrm{mV}$ more negative than this, i.e (from -350 to 550 $\mathrm{mV}$ ) is always observed. The peak current density grows with the exposure time, and it can be attributed undoubtedly to the reduction of the environmentally formed $\mathrm{Ag}_{2} \mathrm{~S}$. No reduction peaks could be observed for unexposed $\mathrm{Ag}$ samples. The background current density, measured on unexposed samples, or estimated on exposed samples as the current minimum between the $\mathrm{Ag}_{2} \mathrm{~S}$ peak and the hydrogen evolution region, ranged between 0.2 and $1 \mu \mathrm{A} \mathrm{cm}^{-2}$, indicating the reduction of residual $\mathrm{O}_{2}$ dissolved in the electrolyte. The coupons exposed at urban sites, i.e. Rodoviária, Borges and Azenha, (Figures 1-3, respectively) showed less pronounced reduction peaks, comparing to the ones exposed at the oil refinery sites, REFAP1 and REFAP2 (Figures 4 and 5). For exposures at the less aggressive sites Borges and Azenha, a clear identification of the reduction peaks, at a potencial sweep rate of $0.1 \mathrm{mV} \mathrm{s}^{-1}$ was only possible for exposure times of $c a .10$ days or longer. For the more aggressive sites at the refinery, clear peaks were already identified after seven days of exposure.

Samples exposed for more then 20 days at the most aggressive sites showed a second reduction peak (Figure $1,4,5)$. Its current density, subtracting the background current, grows with time of exposure and with the aggressivity of the atmosphere, and its current was allways less than $3 \%$ of the main $\mathrm{Ag}_{2} \mathrm{~S}$ peak. A second reduction peak was also observed by the reduction of $\mathrm{Ag}$ samples tarnished strongly in aqueous sulfide solutions of $0.01 \mathrm{~mol} \mathrm{~L}^{-1}$ 


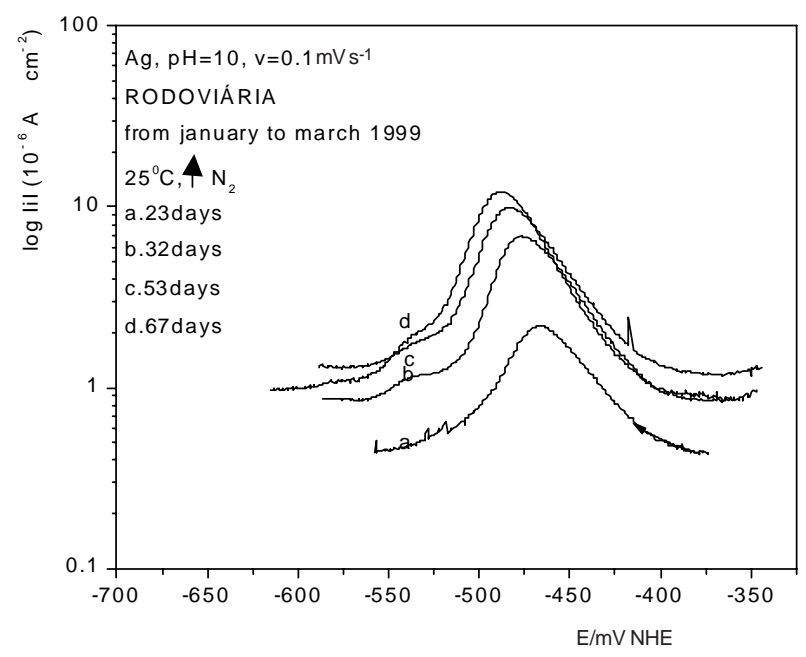

Figure 1. Voltammograms for the reduction of $\mathrm{Ag}_{2} \mathrm{~S}$ on $\mathrm{Ag}$ coupons in borate buffer, $\mathrm{v}=0.1 \mathrm{mV} \mathrm{s}^{-1}$, after atmospheric exposure during January-March 1999 at the Rodoviária site in Porto Alegre.

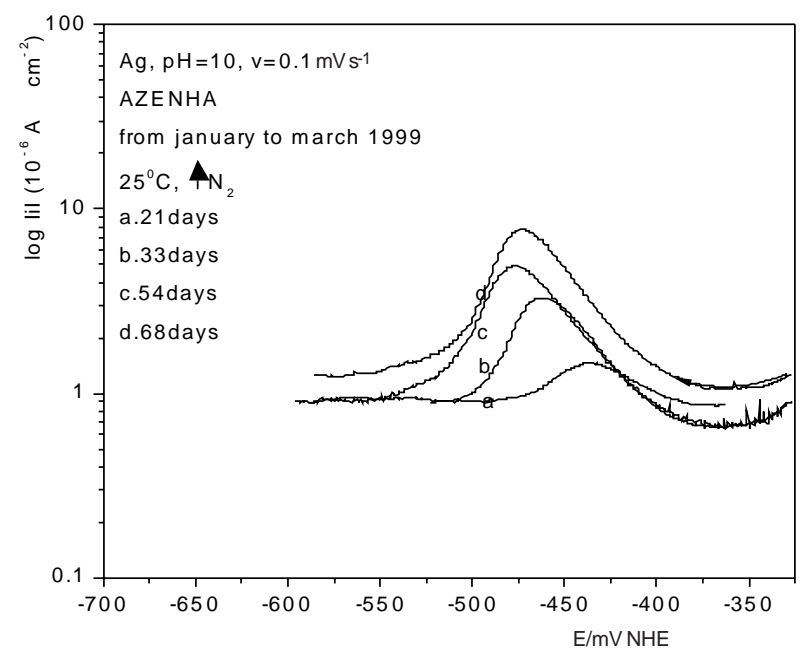

Figure 2. Voltammograms for the reduction of $\mathrm{Ag}_{2} \mathrm{~S}$ on $\mathrm{Ag}$ coupons in borate buffer, $\mathrm{v}=0.1 \mathrm{mV} \mathrm{s}^{-1}$, after atmospheric exposure during January-March 1999 at the Azenha site in Porto Alegre.

$\mathrm{Na}_{2} \mathrm{~S} 6,7$. Only $\mathrm{Ag}_{2} \mathrm{~S}$ could be detected in that case by Xray diffraction and thus, it is here assumed that only $\mathrm{Ag}_{2} \mathrm{~S}$ is formed atmospherically.

The mass of $\mathrm{Ag}_{2} \mathrm{~S}$ formed vs. the exposure time is shown for all sites in Figure 6. For the determination of the respective tarnishing rates, a linear correlation was found for the mass vs. time curves. The correlation coefficients were normally higher then 0.93 , with exception of the Borges site, where $\mathrm{R}=0.70$ was measured. The aggressivity of the sites and the respective $\mathrm{Ag}$ tarnishing rates, lie in the following decrescent order: $\partial \mathrm{m} / \partial \mathrm{t}_{\text {REFAP1 }}=1.00, \partial \mathrm{m} / \partial \mathrm{t}_{R E F A P 2}=0.34$, $\partial \mathrm{m} / \partial \mathrm{t}_{\text {Rodoviária }}=0.08, \partial \mathrm{m} / \partial \mathrm{t}_{\text {Azenha }}=0.06$ and $\partial \mathrm{m} / \partial \mathrm{t}_{\text {Borges }}$ $=0.007 \mu \mathrm{g} \mathrm{Ag}_{2} \mathrm{~S} \mathrm{~cm}^{2}$ day-1$^{-1}$. These results indicate that there are differences of more than one order of magnitude in the tarnishing rates and $\mathrm{SO}_{2}$ concentrations of sites lying only

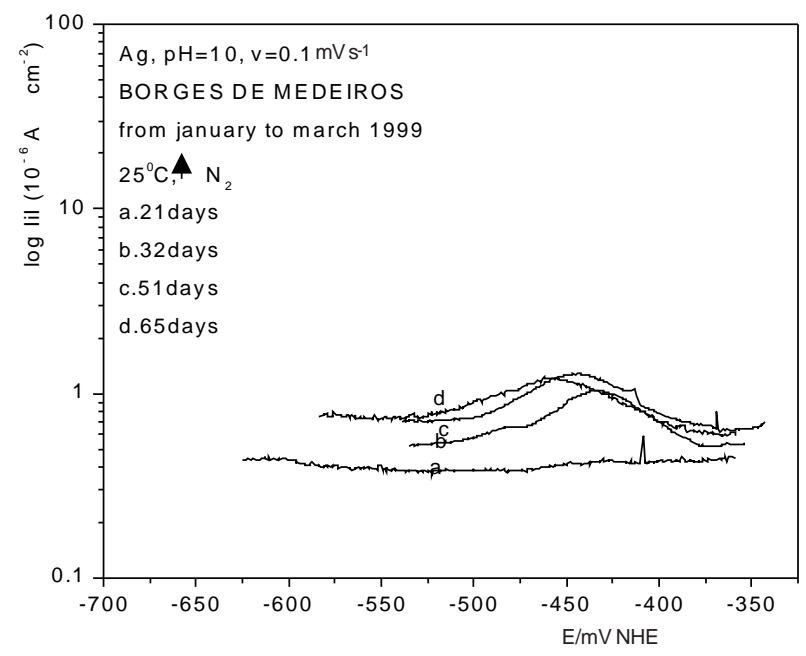

Figure 3. Voltammograms for the reduction of $\mathrm{Ag}_{2} \mathrm{~S}$ on $\mathrm{Ag}$ coupons in borate buffer, $\mathrm{v}=0.1 \mathrm{mV} \mathrm{s}^{-1}$, after atmospheric exposure during January-March 1999 at the Borges de Medeiros site in Porto Alegre.

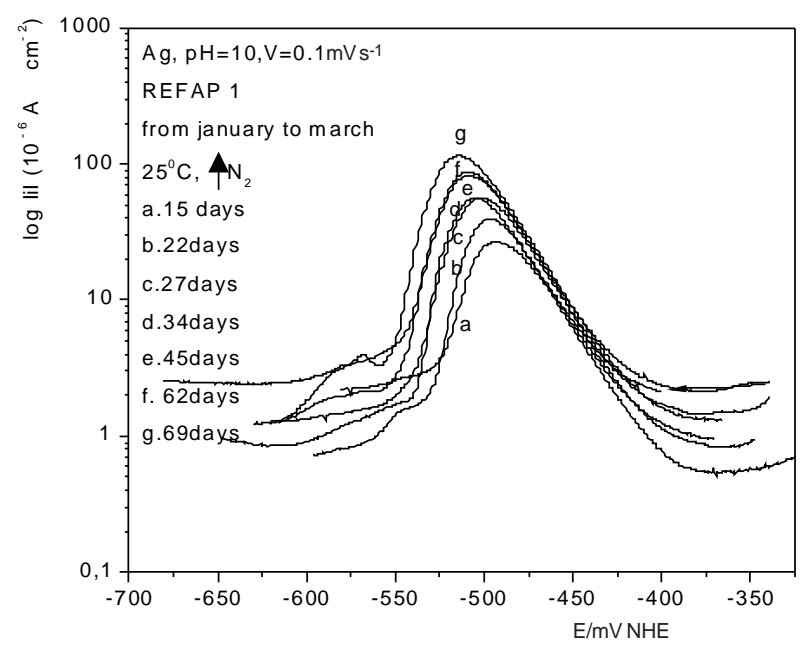

Figure 4. Voltammograms for the reduction of $\mathrm{Ag}_{2} \mathrm{~S}$ on $\mathrm{Ag}$ coupons in borate buffer, $\mathrm{v}=0.1 \mathrm{mV} \mathrm{s} \mathrm{s}^{-1}$, after atmospheric exposure during JanuaryMarch 1999 at the REFAP1 site in Refinaria Alberto Pasqualine.

$1.1 \mathrm{~km}$ apart in downtown Porto Alegre (Borges and Rodoviária). Moreover, for a distance of $2.5 \mathrm{~km}$ from the $\mathrm{H}_{2} \mathrm{~S}-\mathrm{S}_{2}$ source at the refinery, the atmosphere is still 4.25 times more aggressive than the most polluted site identified in downtown Porto Alegre, i.e. Rodoviária.

The comparison between the Ag tarnishing rate and the mean $\mathrm{SO}_{2}$ concentration as determined by daily measurements during the same period with the pararosaniline method is presented in Figure 7. Using the data from the two sites where only $\mathrm{SO}_{2}$ is expected (Rodoviária and REFAP2) a ratio between the $\mathrm{SO}_{2}$ concentration and the $\mathrm{Ag}$ tarnishing rate of $86 \pm 4 \mathrm{~g} \mathrm{SO}_{2} \mathrm{~m}^{-3} / \mathrm{g} \mathrm{Ag}_{2} \mathrm{~S} \mathrm{~cm}^{-2}$ day $^{-1}$. For the site REFAP1, where $\mathrm{H}_{2} \mathrm{~S}$ is also present, a 4 times smaller ratio is found. This is certainly due to a much higher $\mathrm{Ag}$ tarnishing rate in $\mathrm{H}_{2} \mathrm{~S}$ than in $\mathrm{SO}_{2}$. The coulometric 


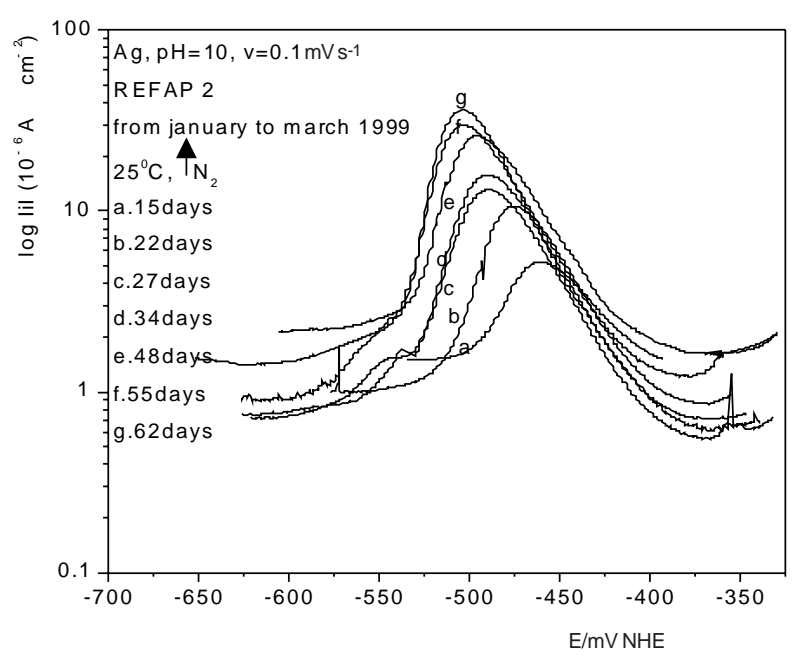

Figure 5. Voltammograms for the reduction of $\mathrm{Ag}_{2} \mathrm{~S}$ on $\mathrm{Ag}$ coupons in borate buffer, $\mathrm{v}=0.1 \mathrm{mV} \mathrm{s}^{-1}$, after atmospheric exposure during JanuaryMarch 1999 at the REFAP2 site in Refinaria Alberto Pasqualine.

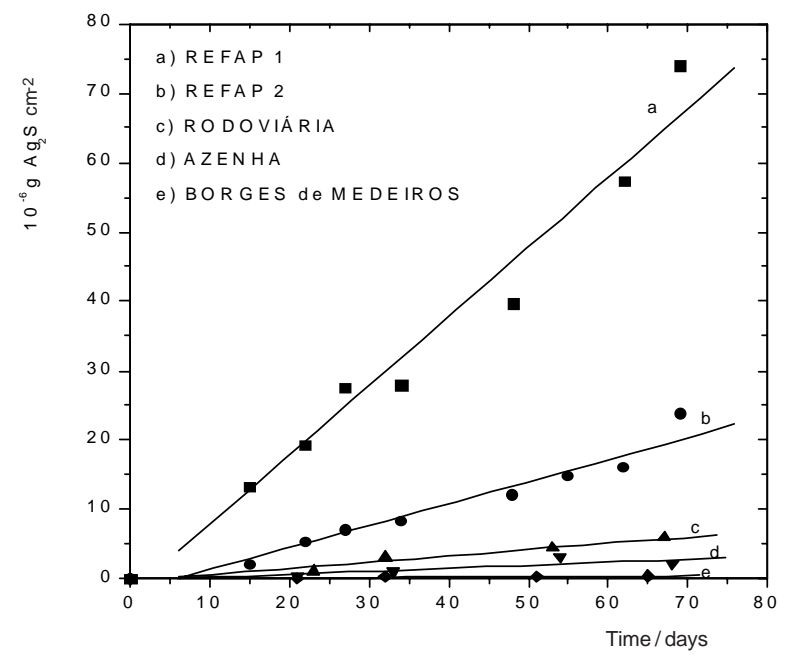

Figure 6. Tarnishing curves of $\mathrm{Ag}_{2} \mathrm{~S}$ growth for $\mathrm{Ag}$ samples exposed at different sites.

method suffers from $\mathrm{H}_{2} \mathrm{~S}$ interference, and no quantitative results can be expected in this case. Even so, it points out that the site REFAPI has a much more aggressive atmosphere than REFAP2. The pararosaniline method, currently in use, indicated $\mathrm{SO}_{2}$ concentration 1.5 times higher at the most distant point from the source than at a closer one. This is probably due to the oxidation of $\mathrm{H}_{2} \mathrm{~S}$ to $\mathrm{SO}_{2}$ in the way between the source and REFAP2.

A comparison between tarnishing rates measured in an environmental chamber 6,7 containing $1 \mathrm{ppm}_{2} \mathrm{~S}$ at $\mathrm{T}=$ $25^{\circ} \mathrm{C}$ and the ones determined in this work at a mean relative humidity of $79.4 \%$ and temperature of $24.9^{\circ} \mathrm{C}$ is presented in Figure 8. Assuming that the tarnishing rate is directly proportional to the $\mathrm{H}_{2} \mathrm{~S}$ concentration, an equivalent $\mathrm{H}_{2} \mathrm{~S}$ concentration can be calculated. The values ob-

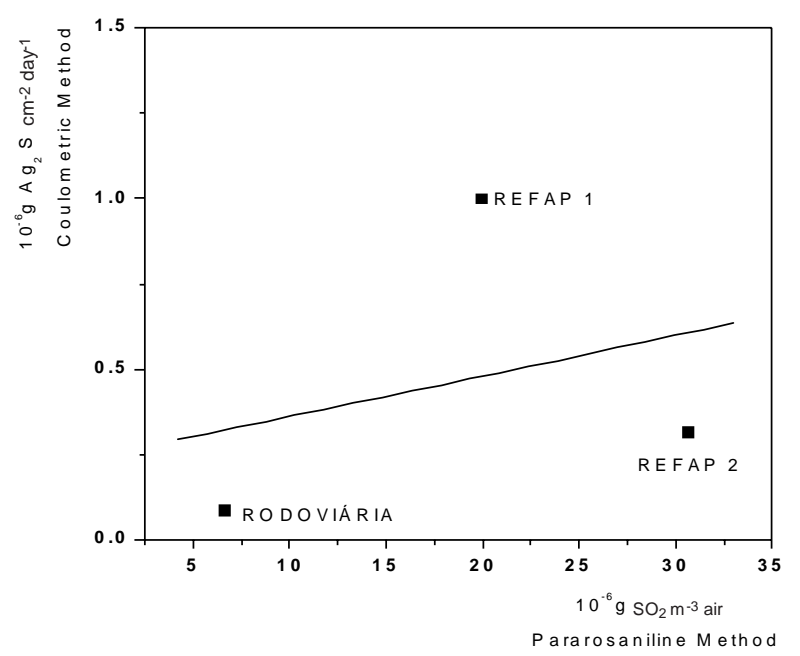

Figure 7. Comparison between the Ag tarnishing rates and the mean $\mathrm{SO}_{2}$ concentration determined by the pararosaniline method.

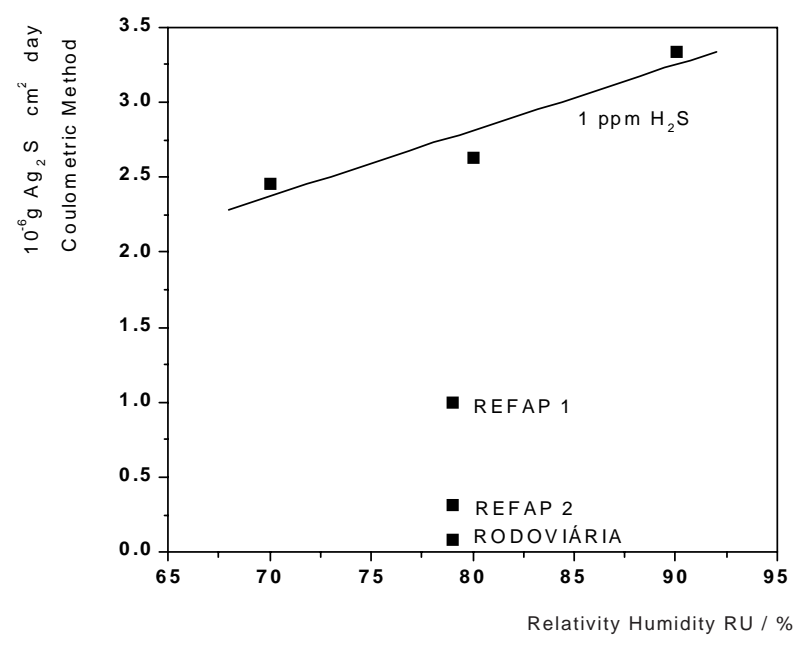

Figure 8. Comparison between the Ag tarnishing rate measured in an environmental chamber at $25^{\circ} \mathrm{C}, 1 \mathrm{H}_{2} \mathrm{~S}$, at 70,80 and $90 \%$ relative humidity and the mean tarnishing rates determined at the monitoring stations.

tained are $0.36 \mathrm{ppm}$ for REFAP1, $0.12 \mathrm{ppm}$ for REFAP2 and 0.03 ppm for Rodoviária.

\section{Conclusions}

The coulometric method, based on the determination of the tarnishing rate of $\mathrm{Ag}$, can be used for the determination of $\mathrm{SO}_{2}$ concentrations in urban atmospheres. When $\mathrm{H}_{2} \mathrm{~S}$ is also present, as in industrial areas, an over estimation of the $\mathrm{SO}_{2}$ concentration is expected, as the method can not separate the effect of these two species. At least one week is necessary till the presence of $\mathrm{SO}_{2}$ can be detected in urban sites. Due to its low cost and simplicity, the method is more adequate for the local determination of long term average concentrations of $\mathrm{SO}_{2}$. 


\section{Acknowledgments}

The Secretaria Municipal do Meio Ambiente from the City of Porto Alegre and the company REFAPPETROBRAS are gratefully acknowledged for technical support. M. Silva thanks CAPES for a fellowship.

\section{References}

1. Pereira, P. M.; Saldiva, P. H. N.; Sakae, R. S.; Bohm, G. M.; Martins, M. A. Environ. Res. 1995, 69, 96.

2. Darlington, T. L.; Kahlbaum, D. F.; Heuss, J. M.; Wolff, G. T. J. Air \& Waste Manage. Assoc. 1997, 47, 1070.
3. Refinaria Alberto Pasqualine Reports- Levantamento sobre a contribuição do setor automotivo na geração de poluentes atmosféricos na região metropolitana de Porto Alegre 1996.

4. Licht, S. J. Electrochem. Soc., 1988, 135, 2971.

5. Franey, J. P.; Kammlott, G. W.; Graedel, T. E. Corros. Sci. 1985, 25, 1163.

6. Dick, L. F. P.; Kaiser, H. Kaesche, The Electrochem. Soc. Softbound Proc. Series, Pennington NJ, 1993, p 406.

7. Dick, L. F. P.; Kaiser, H. Kaesche, The Electrochem. Soc. Softbound Proc. Series, Pennington NJ, 1991, p 273.

8. Annual Book of ASTM Standards, 1972, 23, 843.

Received: June 01, 1999 